\title{
Darwinism, organizational evolution and survival: key challenges for future research
}

\author{
Gianpaolo Abatecola • Fiorenza Belussi • \\ Dermot Breslin • Igor Filatotchev
}

Published online: 5 February 2015

(C) Springer Science+Business Media New York 2015

\begin{abstract}
How do social organizations evolve? How do they adapt to environmental pressures? What resources and capabilities determine their survival within dynamic competition? Charles Darwin's seminal work The Origin of Species (1859) has provided a significant impact on the development of the management and organization theory literatures on organizational evolution. This article introduces the JMG Special Issue focused on Darwinism, organizational evolution and survival. We discuss key themes in the organizational evolution research that have emerged in recent years. These include the increasing adoption of the co-evolutionary approach, with a particular focus on the definition of appropriate units of analysis, such as routines, and related challenges associated with exploring the relationship between co-evolution, re-use of knowledge, adaptation, and exaptation processes. We then introduce the three articles that we have finally accepted in this Special Issue after an extensive, multi-round, triple blind-review process. We briefly outline how each of these articles contributes to understanding among scholars, practitioners and policy makers of the continuous evolutionary processes within and among social organizations and systems.
\end{abstract}

\footnotetext{
G. Abatecola $(\bowtie)$

University of Rome “Tor Vergata”, Via Columbia 2, 00133 Rome, Italy

e-mail: gianpaolo.abatecola@uniroma2.it

F. Belussi

University of Padua, Via del Santo 33, 35122 Padua, Italy

e-mail: fiorenza.belussi@unipd.it

D. Breslin

Sheffield University Management School, Conduit Road, Sheffield S10 1FL, UK

e-mail: d.breslin@sheffield.ac.uk

I. Filatotchev

Sir John Cass Business School, City University London, 106 Bunhill Row, London EC1Y 8TZ, UK e-mail: Igor.Filatotchev@city.ac.uk
} 
Keywords Darwinism $\cdot$ Adaptation $\cdot$ Co-evolution $\cdot$ Exaptation

\section{Introduction}

How do social organizations evolve? How do they adapt to environmental pressures? What resources and capabilities determine their survival within dynamic competition? Undoubtedly, Charles Darwin's seminal work The Origin of Species (1859) has provided a significant impact on the development of the management and organization theory literatures on organizational evolution. In particular, and in the light of the challenges facing us in the 21 st century, there is a need to explore the "fascinating but difficult new questions about the complex nature of the relationships between brain, genes, and human and social behaviour" (European Science Foundation's Standing Committee for the Social Sciences 2013: 5).

Although the potential contribution of Darwinism to our understanding of how not only biological organisms (e.g. Laland et al. 2014), but also firms and other social organizations evolve, remains debated at present, a number of diverse research approaches that, narrowly or more widely, build on the evolutionary perspective, have been growing over time. For example, a number of management and organization theory scholars has attempted to explain organizational evolution, in terms of change, survival or growth, through meaningfully applying Darwin's principles of evolution in the natural sciences. To this end, this research stream has synthesized, more than once, these principles into the process of "variation" (of the genotype), "selection" (of its related phenotype) and "retention" (of the underlying genotype). Alternatively, scholars have attempted to explain organizational evolution through applying the theory of "punctuated equilibrium" proposed by the palaeontologists Gould and Eldredge (1977). Over time, "co-evolutionary" accounts of the competitive or cooperative relationships between social organizations and their environment have also flourished, with their conceptual basis mostly grounded in considering these relationships as dialectical and circular. There is a need to build solid conceptual foundations for the various strands of research that either directly use evolutionary approaches or conduct co-evolutionary studies with little reference to related evolutionary principles. We argue that evolutionary theory offers the unique possibility to study the multi-level, longitudinal and systemic nature of organizational change.

On this premise, this article introduces a Special Issue "Darwinism, organizational evolution and survival", hosted by the Journal of Management and Governance and associated with a track of the 2012 Annual Conference of the European Academy of Management (EURAM) that has the same title. Over the years, this EURAM track has attracted scholars and practitioners interested in adopting theory-led, holistic, memetic or multi-level/co-evolutionary approaches to studying phenomena associated with the evolution and survival of both social organizations and socio-economic systems. This innovative track aims to build on a constantly growing body of evolution-based research within a wide range of disciplines such as management, organization, entrepreneurship and innovation, economic geography, philosophy and psychology. 
Organizational evolutionists acknowledge that both common features and differences exist in how organisms and organizations behave. At the same time, they share a common belief that various assumptions constituting the nature of the evolutionary approach can serve as a research method particularly appropriate not only to the scientific community, but also to the practice of business, for understanding the many challenges faced by social organizations and economies. Examples include the studying of global phenomena such as the current financial crisis; the different rates of organizational birth and infant death worldwide; the competition or integration between social systems, national and international communities; the diverse adoption of technological innovation, and even the way through which culture, beliefs, values and norms diffuse. In particular, differently from many of the mainstream traditional approaches to management and organization theory, organizational evolutionists maintain that the aforementioned phenomena cannot be properly accounted for through focusing on organizations, or their environments, as stand-alone, single and static units of investigation. Moreover, they believe that multi-level, dynamic, co-evolutionary narratives can better inform management and organizations as they move forward to face the challenges of an ever-increasing turbulent global economy.

In this editorial article, we first discuss key themes in the organizational evolution research that have emerged in recent years. These include attention to the increasing adoption of the co-evolutionary approach, with a particular focus on the definition of appropriate units of analysis, such as routines, and the related challenges associated with the relationship between co-evolution, re-use of knowledge, adaptation, and "exaptation" processes. We then introduce the three articles in this Special Issue, which we have selected after an extensive, multi-round, triple blind-review process. In this regard, we briefly outline how each of these articles can contribute to the understanding of scholars, practitioners, and policy makers of the continuous adaptation and evolutionary processes within and among social organizations and systems.

\section{The diffusion of the co-evolutionary approach within management research}

Our search of the Business Source Complete database in September 2014 provided interesting and exciting evidence about the significant diffusion of the coevolutionary approaches within the management domain over time. In particular, after scanning Business Source Complete through the keywords "coevol*" OR "coevol*" in the articles' abstracts, the results show that 870 journal articles associated with co-evolution have been published, to date. More importantly, 794 articles (i.e. $91 \%$ ) have been published since 2000, indicating a significant increase in publications over the last 10 years.

These publication statistics seem to suggest that co-evolution is definitely on the rise within the research agenda of management scholars, although the genesis of the co-evolutionary approach in the management field dates back to the seminal research of Weick's (1969) thinking in circles and Benson's (1977) dialectical view of the relationship between social organizations and their environment. In this 
regard, while some scholars (e.g. Astley and Van de Ven 1983; Bedeian 1990; Bourgeois 1984; Cafferata 1984, 1987; Hrebiniak and Joyce 1985; Levinthal 1991, 1992; Price and Shaw 1998; Whittington 1988) have offered innovative conceptual explanations of this relationship, others have conducted seminal empirical analyses, especially in the pottery (Langton 1984), manufacturing (Lawless and Finch 1989; McCarthy 1995; McCarthy et al. 1997; Pettigrew 1987) and semiconductor (Burgelman 1991) industries.

Generally speaking, co-evolution is, to date, mostly conceptualized as the effect of the dynamic process of combination between strategic pro-activity and environmental boundaries (e.g. Breslin 2014; Cafferata 2014a; Child et al. 2013; Hodgson 2013; Mazzucato 2013; Murmann 2013; Stoelhorst and Richerson 2013; Volberda et al. 2014). Moreover, in the past decade, scholars have highlighted how, over the years, the studies about co-evolution have been taking heterogeneous directions of analysis in terms of both conceptual and applied research (Baum 2002; Dosi et al. 2003; Durand 2006; Lewin and Koza 2001; Lewin and Volberda 2005). For example, co-evolution has been associated with different facets regarding competition, such as strategic renewal, technological innovation, industrial dynamics, absorptive capacity, or networks' formation (Abatecola 2014a).

In terms of their context, prior studies have explored firms based in Europe and the US, and within a wide diversity of industry and organizational settings, including luxury fashion (Djelic and Ainamo 1999), synthetic dye (Murmann 2003), entertainment (Huygens et al. 2001; Jones 2001), financial services (Flier et al. 2003; Koza and Lewin 1999; Levinthal and Myatt 1994), family business (Carney and Gedajlovic 2002), telecommunication (Rodrigues and Child 2003), and Formula One racing (Jenkins and Floyd 2001). A common theoretical feature of these diverse investigations is that the research approach used has been mostly qualitative, with case studies conducted during extended time periods and using multilevel observations (i.e. at country, industry, and firm levels simultaneously).

At present, there is an emerging consensus to consider co-evolution as a powerful tool for explaining competition and change within and among socio-economic systems. For example, scholars have recently improved their efforts to consider coevolution as an important theoretical framework for interpreting phenomena in different fields, such as strategic, knowledge and marketing management (Abatecola 2012a, 2014b; Dantas and Bell 2011; Furnari 2014; Johansson and Kask 2013), entrepreneurship and global sourcing (Bellavitis et al. 2014; Koza et al. 2011; Lewin and Volberda 2011; Pacheco et al. 2010; Najat and Maclean 2013), creativity, innovation and culture (Belussi and Staber 2011; Gatti et al. 2015; Gill 2012; Lord 2012; Mazzucato and Tancioni 2008; Price 2012; Vagnani 2012), and urban planning/real estate management (Alexander and Price 2012; Dobson 2012; Dobson and Jorgensen 2015). Moreover, at a theoretical level, some scholars (e.g. Breslin 2011, 2015; Murmann 2013) have renewed past attempts (e.g. Baum and McKelvey 1999; Baum and Singh 1994; Jones 2005; Murmann 2003; Volberda and Lewin 2003) aimed at conceptually combining mechanisms of co-evolution with those of Darwinian variation, selection and retention.

In sum, co-evolution can help us understand multilevel mechanisms of competition and change in both low and high velocity environments (Ethiraj and 
Levinthal 2004; Hodgson 2010; McCarthy et al. 2010). Of course, what we have stated here opens the door not only to the exploitation of past and current research streams, but, as we argue below, also to the exploration of new research methodologies in the future. For example, combining quantitative and qualitative data and research methods can create a significant research value added. Moreover, new conceptual research questions also seem to emerge, such as: Has the meaning of co-evolution in the management research been changing over time? Has the use of this approach really been reflecting the logic of co-adaptation between the living organisms and their environment, as suggested by Charles Darwin? (Cafferata 2014b).

\section{Defining the unit of analysis in organizational co-evolution}

In developing theoretical co-evolutionary frameworks, Baum and Singh (1994) stress the importance of defining units of analysis at each level within an organizational hierarchy. These co-evolving units are discrete classes of "entities" with their own evolutionary path, which at the same time interact with "entities" at other levels. While a number of scholars have adopted the word "co-evolution" to describe the multi-level interactions within organizations, few have drawn from other domains to further develop the theoretical foundations of such a coevolutionary approach (Breslin 2015; Dollimore and Gomes 2014).

As noted above, some scholars have suggested mechanisms of variation, selection and retention to provide a conceptual account of co-evolution in organizations. More recently, a consensus amongst a group of these scholars has emerged around the use of these three mechanisms and the additional concepts of the "replicator" and "interactor". The replicators-interactors are the abstract concepts from biological evolution, where the replicator is defined as anything in the universe of which copies are made, such as genes in the biological world. Interactors have been defined as entities that interact as a cohesive whole with their environment in a way that causes a differential replication of these elements (Hull 1988). The use of the replicator-interactor concept, alongside variation-selectionretention, has been labelled the "Generalized Darwinist" approach, which argues that, at a sufficiently general level of abstraction, a core set of general Darwinian principles can be used to describe evolution within a variety of domains (Aldrich et al. 2008; Breslin 2011; Campbell 1965; Hodgson and Knudsen 2010), including biology, psychology, culture and economics. In this manner, whilst the details of socio-economic evolution may be different from biological evolution, the concept of Generalized Darwinism can nonetheless be used as the starting point for the development of theory in both.

Scholars who have studied organizational co-evolution through this heuristic lens have focused on the routine as the unit that co-evolves. In many respects, the adoption of the routine dates back to the notion of the "routine as gene" introduced in Nelson and Winter's (1982) seminal work An Evolutionary Theory of Economic Change. While the concept is generally defined as a collective phenomenon, whose enactment results in recurrent patterns of action (Becker 2005; Nelson and Winter 
1982), different conceptualizations have led to quite distinct evolutionary narratives. Some have tended to conceptualize the routine as a capability or entity (Breslin 2015), with a focus on how these phenomena influence wider organizational performance. For instance, Nelson and Winter (1982) conceptualize the routine as a reflex-like, automatic process in which individuals within a group respond to certain stimuli with a particular set of repeated actions. As a result, it is assumed that routines are enacted in an automatic sense, with little variation over time, and so their evolution largely depends on external selection forces affecting the organization, as opposed to endogenous change by the individuals enacting them (Feldman and Pentland 2003). It is thus argued that the fate of these routines is inextricably linked to that of the organization (Hodgson and Knudsen 2010). However, this routine-organization dualism (and associated evolutionary accounts) has been criticized, as the voice of the individual and agency is lost, excluding the possibility of intentionality, learning (Witt 2004), motivation, creativity, imagination and deliberate adaptations (Cordes 2006).

In the light of this criticism, other researchers have suggested a "practice" view of routines, in which the focus shifts to parts of routines (Rerup and Feldman 2011), how they are enacted on a day-to-day basis, and their internal dynamics. Parmigiani and Howard-Grenville (2011) argue that the practice perspective opens the black box of routines and their internal workings in specific organizational contexts. While the definition of the routine as a repetitive pattern of actions is similar to the entity approach, the emphasis here is on how these patterns are produced and reproduced, and to what extent the patterns remain stable over time (Parmigiani and Howard-Grenville 2011). Pentland and Feldman (2005) introduced the "ostensiveperformative" duality to conceptualize this adaptive, improvisational nature of routines. They define the performative aspect of the routine as the "actual performances by specific people, at specific times, in specific places", as opposed to the ostensive aspect of routines which are "abstract or generalized patterns that participants use to guide, account for and refer to specific performances of a routine" (Pentland and Feldman 2005: 795). Evolutionary accounts have likewise been developed in which the replicator-interactor is defined through the ostensiveperformative duality (Breslin 2015). In this manner, behaviours (as represented by the performative aspect) are varied and selectively retained through the ostensive aspect over time, or, in other words, variations in performance are selectively retained through the guiding story or ostensive aspect (Feldman and Pentland 2003).

This "practice" focus marks a conceptual shift in emphasis within research on organizational change and co-evolution. In the entity approach, change is seen as occurring through the birth and death of routines as entities. In the practice view, the routine itself evolves and changes over time. In the entity view, the focus of attention thus remains largely on the level of organization, with managers making choices on behalf of the firm (Levitt and March 1988), and, as a result, above the level of individual learning (Schulz 2002). This entity-based view is consistent with a "gradualism" interpretation of evolution as we discuss later, with population-level change occurring through organizational births and deaths. If one assumes that change occurs in this manner, then it becomes difficult to explain the phenomenon of punctuated equilibrium (Gould and Eldredge 1977) seen in nature and economic 
life. On the other hand, if one assumes that change occurs at multiple levels (including group- and individual-level learning), then evolutionary accounts can produce patterns of change that can be both gradual and punctuated, as Breslin (2014) demonstrated using computational modelling techniques. Addressing this problem, some have expanded the entity view by identifying units of evolution at different levels of analysis (Baum and Singh 1994; Hodgson and Knudsen 2010).

Despite the multi-level nature of these proposed solutions, there is still a key assumption that evolving routines are ultimately tied to the individuals, groups and organizations concerned (Breslin 2015). On the contrary, some have recently argued that change and innovation are enacted and effectuated through interactions between individuals. With practice-based evolutionary accounts, the replicator-interactor concept is represented as a mutually constituted duality of cognitive representations and manifest behaviors/narratives respectively. However, most of these accounts again tend to focus exclusively on only one level of analysis. For example, Pentland et al. (2012) focus on the group as a level of analysis, with routines evolving and adapting in a mutually constitutive relationship between the ostensive guide and performative aspect. However, as noted above, some have identified units of analysis at different levels in the development of co-evolutionary accounts. So, individuals and collective cognitive structures represent the replicators at the level of the individual, group and organization respectively (Breslin 2008). The corresponding interactor depends on the "micro-environment within which selection occurs, namely the set of actions performed by individuals, groups or firms" (Breslin 2008: 412). Disconnecting the fate of routines and knowledge from the groups and those individuals enacting them opens up new evolutionary paths, including those unrelated to historical developments, as knowledge becomes adapted to new uses through a process known, as we explain in Sect. 4, as "exaptation" (Dennett 1995).

To summarize, the co-evolutionary narratives differ, depending on whether one uses an entity- or practice-based interpretation of the replicator-interactor. In the first case, routines are viewed as repositories tied to the life of individuals and groups. The evolution of these entities is experiential and, as a result, path dependent. In these entity-based accounts, if one assumes that population change occurs through births and deaths alone, then punctuated equilibrium becomes problematic. In practice-based narratives, knowledge is viewed as being enacted in practice, and having an existence through those actions. As a result, these narratives are not necessarily tied to the fate of the individuals and groups concerned. Knowledge can thus co-evolve between levels of analysis, resulting in both gradual and punctuated change patterns at the population level (Breslin 2014). In addition, freed from the ties of specific individuals and groups, knowledge can evolve, as it becomes adapted to new uses and environmental challenges. Examining these differences in approach, the choice to use a practice- or entity-perspective depends on the relationship between organizational and environmental change. Within the entity view, it is assumed that the external environment (or that external to the entity in question) changes more rapidly than the associated individual or group. On the other hand, within the practice view, one assumes that individuals and groups can adapt dynamically (and indeed prospectively) to external change. So, while multilevel narratives can be developed using both approaches, the different positions 
reflect the long-standing dichotomy between deterministic and voluntaristic perspectives. In the former it is assumed that structural inertia and environmental change have primacy, whereas in the latter adaptation and strategic choice dominate (Abatecola 2012b; Breslin 2008).

\section{Co-evolution, re-use of knowledge, adaptation, and exaptation}

Traditional theories of innovation explain the technological trajectory of firms by stressing discontinuities existing within the firm's innovation process (Tushmann and Anderson 1986). As highlighted by the Schumpeterian tradition, radical innovations emerge erratically by chance, when dynamic entrepreneurs who are exploring new market opportunities introduce "new combinations" moving the entire economic system away from equilibrium (Schumpeter 1934, 1947). Economists focus mainly on the analysis of breakthrough innovations, but, after the end of the 1970s, the economic importance of marginal technical improvements has also become acknowledged (Basalla 1988; Dosi 1982; Freeman 1982, 1984; Rosenberg 1976, 1982).

But what drives innovation? Many authors, including Chesbrough (2003) and Arthur (2007), have stressed the non-linearity of the innovation process, and the role of multiple drivers of innovation activity of firms. As discussed by Mokyr (2000: 18): "Much if not most creativity comes from the manipulation of what is already known, rather than in the addition of totally new knowledge". The creation of new knowledge or the re-use of existing knowledge is clearly not enough: a combination of alertness and effectual behaviour (Mastrogiorgio 2013) allows entrepreneurs to look at resources and technologies as "interpretative flexible" entities (Bijker 1987), or entities whose services are a "function of the ways in which they are used" (Penrose 1959: 25). Indeed, as Dew et al. (2004) suggest, there is evidence that entrepreneurs behave effectually, namely they act to fabricate their own environments and futures. However, co-evolution is guided by both intentional strategies and adaptive reactions to modified external conditions. The process of variation, retention, and environmental selection (Abatecola 2014a; Breslin 2011; Volberda and Lewin 2003) clearly involves not only the production of new knowledge, but also adaptation, and often an exaptive re-use of knowledge applied to new domains. There is a creative dimension in the post-application of already existing knowledge into new domains, which induces a flow of innovations ("cascade" innovations) and percolation processes (Antonelli 2011; Lane 2011; Watts 2002). From this perspective, change is endogenous to firms (Nelson and Winter 1982), and the environment is the emergent construct of market competition.

As we indicated above, firms do not only adapt to external changes, but also proactively co-construct their competitive environment. Evolutionary theories of economic change have been mostly used to explain discontinuities in the firm's innovation process, while adaptation has been the focus of a growing stream of literature within business studies and managerial approaches to the organization that suggests taking into consideration the important issue of "continuous evolution". However, these two perspectives have merged within the theory of dynamic capabilities (Eisenhardt and Martin 2000; Helfat et al. 2007; Teece 2007; Teece 
et al. 1997; Winter 2003; Zollo and Winter 2002). We need to consider the existing interregnum between discontinuous and continuous innovations, and between radical and incremental changes, in terms of gradualism (Antonelli 2007; Levinthal 1998), reconfiguration process in technological transition (Geels 2002; Meyer and Stensaker 2006), reconfiguration of operational and dynamic capabilities (Di Stefano et al. 2010; Helfat and Winter 2011), pre-adaptation, adaptation and selection of capabilities (Fortune and Mitchell 2012). In contrast to what Darwin originally proposed, "speciation" (i.e. the birth of new and distinct biological species) is not always determined by the long-term, gradual accumulation of diverging adaptive changes positively selected by the environment; it can also derive from a punctuated equilibrium (Gould 1982; Gould and Eldredge 1977). The migration in a new niche triggers a divergent evolutionary path. To frame nonadaptive processes, Gould and Vrba (1982) suggested the term "exaptation", which refers in biology to characters that have "evolved for other usages (or for no function at all) that are later "coopted' for their current role" (Gould and Vrba 1982: 6). Exaptation mirrors the application of existing technology into a new domain of application, precipitating a process of evolution of prior technologies into new innovative artefacts.

Exaptation is not the result of a Darwinian selection process, but the output of a co-evolution between internal and external forces that trigger variation. This approach is helpful in explaining the emergence of discontinuous and continuous change as a historical sequence of knowledge re-combination, new inventions, and exaptation. Larson et al. (2013) emphasise that, often, the terms "adaptation" and "exaptation" overlap, and that all adaptations can be exaptations. Other authors (Dew et al. 2004; Bonifati 2010; Bonifati and Villani 2013; Lane 2011), in contrast, clearly define exaptation as a new pattern of interaction among agents around the use of new kinds of artefacts leading to the emergence of a new functionality. In order to distinguish adaptation from exaptation, Bonifati and Villani (2013) suggest that while adaptation processes can be derived from their actual functionality, the origin of the artefacts created by exaptation processes cannot be derived from their current utility. Dew et al. (2004) specify that exaptation refers to connecting a technology with a new domain of use, not on technology-technology combinations. Exaptation processes include an initial exaptation followed by subsequent processes towards "aptation", with this term generally indicating the "static phenomenon of being fit" (Gould and Vrba 1982: 6). The latter processes are characterised by continuous positive feedbacks, induced externalities, innovation cascades, and interactions.

The exploitation of an innovation may follow a specific technological trajectory, which is linearly explained by a continuous innovation path that develops over time (Dosi 1982). Accidentally, an exaptive event can lead to an exaptation, which extends and multiplies the technological trajectory of innovation, creating eventually a venue for a new exaptive pattern, which Lane (2011) named the "exaptive bootstrapping process". As a result, innovation cascades along a variety of technological trajectories occur, depending on the extension of the agent/artefact space. Generative collaborations within an innovation ecosystem, that enlarge the space of possibilities and identify new systems of use alongside the discovery of new functionalities, are crucial (Bonaccorsi 2011). From this perspective, 
exaptations precede adaptations (Andriani and Cohen 2009). In particular, recent contributions to the topic have emphasized the importance of external relational capabilities (Hagedoorn and Duysters 2002; Helfat et al. 2007; Inkpen 2000), which can be developed through strategic alliances and acquisitions. External dynamic capabilities may be used to shape the ecosystem occupied by a firm, developing new product and processes, and designing viable business models (Teece 2007). A firm can be seen as a nexus of network relationships with partners, clients and suppliers, which build the business ecosystem (Hargadon and Sutton 1997; Powell 1990; Powell et al. 1996; Sorenson et al. 2006). Therefore, a company can be viewed not as a member of a single industry, but as part of an innovation ecosystem that crosses a variety of industries. An environmental context where complementary firms, suppliers, regulatory authorities, standard-setting bodies, the judiciary, and educational and research institutions play a relevant role in the choice of the strategic orientation of the firm (Teece 2007). Network position and absorptive capacity (Cohen and Levinthal 1990) are two fundamental conditions that support the innovation process. The network position of the firm affects its propensity to be involved in knowledge flows that can potentially be drivers of exaptation (Cattani and Ferriani 2008).

Far from being deterministic, this process is characterised by what Lane and Maxfield (2005) call "ontological uncertainty". Exaptation may occur within multiple paths. Three phases characterise the process of exaptation: (1) accumulation of knowledge from internal and external sources (this process can be either emergent or deliberate); (2) existing knowledge is co-opted for new uses in new market domains (different degrees of exaptation might exist, according to the distance between the old and the new market domain); (3) the co-opted knowledge expands the innovation ecosystem of the firm, creating new venues for innovation cascades. Therefore, exaptation may occur throughout the re-use of knowledge in the same technological classes or in the same sector ("narrow" exaptation) or in distant classes or in different sectors ("extensive" exaptation), as discussed by Belussi et al. (2015). More importantly, exaptation may sustain the creation of a complex and multilevel dynamic innovation ecosystem (Marquis and Huang 2010; Moore 1993), or a broad community of organizations, institutions and individuals that affect the innovation capacity of the enterprise and of the enterprise's customers and suppliers (Carayannis and Campbell 2009). As argued by Andriani and Cohen (2013), the co-construction of niches reintroduces multilevel dynamics to evolutionary explanations. The emergence of new niches requires a parallel transformation of agents and environments since technologies cannot evolve without pre-existing markets, nor can new markets emerge without societal applications of new technologies.

\section{Papers in the Special Issue}

We have discussed some key themes in the organizational evolution research emerging in recent years. We believe that ideas and arguments presented above can serve as a useful introduction to the three articles finally accepted for publication in this Special Issue. 
The Special Issue opens with the article written by Roberto Cafferata and entitled Darwinist Connections between the Systemness of Social Organizations and their Evolution. Is the systemness of social organizations a determinant of their evolution? As Cafferata explains, this pivotal research question has not yet received appropriate attention by the literatures on management and organization theory. Thus, he attempts to fill this gap through adopting a critical Darwinist approach, which also directly refers to the content of Darwin's Origin of the Species. In particular, Cafferata's hypothesis is that "social organizations can be neither homologous with biological creatures, nor perfectly homologated to them, although they show some structural and behavioral features in common with the organisms studied by Darwin himself" (p. 4).

The Special Issue continues with the article written by Dermot Breslin and entitled What Evolves in Organizational Co-Evolution? Breslin examines in detail how different scholars have conceptualized the evolutionary process in social systems, with regard to the unit of co-evolution. Reviewing literatures on innovation, change and organizational learning, Breslin identifies two broad approaches taken: namely, the "entity" and "practice" views. He then considers the implications of adopting both perspectives when considering the conceptualization of organizational co-evolution and related empirical investigations.

The Special Issue ends with the article written by Colin Jones and entitled An Autecological Interpretation of the Firm and its Environment. Jones presents an alternative view for studying organizations as ecologies, namely the "autecological" approach. In contrast to traditional, well-established organizational ecology, the proposed autecological approach to the study of firms is based on accounting for environment heterogeneity and the ways in which different environmental variables relate to firms in unique ways that ultimately determine their ability to survive. This addresses a bias in existing ecological approaches towards competition as the primary organizing process through which firm survival is explainable. The article also considers several emergent research opportunities that highlight the potential value of applying an autecological approach to the study of organizations.

In conclusion, we would like to acknowledge all those people and organizations who helped to develop this Special Issue. First, we would like to thank Springer and Roberto Di Pietra, Editor of the Journal of Management and Governance, for providing us with this opportunity to reach out to a growing community of scholars committed to advancing evolutionary studies. Second, we would like to express our gratitude to all the authors who submitted their articles. Third, we would like, of course, to extend our gratitude to all our reviewers.

We hope that all the efforts involved in this challenging project will contribute to further evolution of Darwinism in the management and organization theory research.

\section{References}

Abatecola, G. (2012a). Interpreting corporate crises: Towards a co-evolutionary approach. Futures, 44(10), 860-869. 
Abatecola, G. (2012b). Organizational adaptation. An update. International Journal of Organizational Analysis, 20(3), 274-293.

Abatecola, G. (2014a). Research in organizational evolution. What comes next? European Management Journal, 32(3), 434-443.

Abatecola, G. (2014b). Untangling self-reinforcing processes in managerial decision making. Coevolving heuristics? Management Decision, 52(5), 934-949.

Aldrich, H. E., Hodgson, G. M., Hull, D. L., Knudsen, T., Mokyr, J., \& Vanberg, V. J. (2008). In defence of generalized Darwinism. Journal of Evolutionary Economics, 18(5), 577-596.

Alexander, K., \& Price, I. (Eds.) (2012). Managing organizational ecologies: Space, management and organizations. New York: Routledge.

Andriani, P., \& Cohen, J. (2009). Innovation in biology and technology: Exaptation precedes adaptation. Paper presented at the international workshop on "Exaptation", Gargnano del Garda (Italy), 7-9th Sept.

Andriani, P., \& Cohen, J. (2013). From exaptation to radical niche construction in biological and technological complex systems. Complexity, 18(5), 7-14.

Antonelli, C. (2007). The system dynamics of collective knowledge: From gradualism and saltationism to punctuated change. Journal of Economic Behavior \& Organization, 62(2), 215-236.

Antonelli, C. (Ed.) (2011). Handbook on the economic complexity of technological change. Cheltenham: Edward Elgar.

Arthur, B. W. (2007). The structure of invention. Research Policy, 36(2), 274-287.

Astley, W. G., \& Van de Ven, A. H. (1983). Central perspectives and debates in organization theory. Administrative Science Quarterly, 28(2), 245-273.

Basalla, G. (1988). The evolution of technology. Cambridge: Cambridge University Press.

Baum, J. A. C. (Ed.) (2002). The Blackwell companion to organizations. Oxford: Blackwell Publishing.

Baum, J. A. C., \& McKelvey, B. (1999). Whole-party co-evolutionary competition in organizations. In J. A. C. Baum \& B. McKelvey (Eds.), Variations in organization science: In honour of Donald $T$. Campbell (pp. 113-135). London: Sage Publications.

Baum, J. A. C., \& Singh, J. (Eds.) (1994). Evolutionary dynamics of organizations. New York: Oxford University Press.

Becker, M. C. (2005). A framework for applying organizational routines in empirical research: Linking antecedents, characteristics and performance outcomes of recurrent interaction patterns. Industrial and Corporate Change, 14(5), 817-846.

Bedeian, A. G. (1990). Choice and determinism. A comment. Strategic Management Journal, 11(7), 571-573.

Bellavitis, C., Filatotchev, I., \& Kamuriwo, S. (2014). The effects of intra- and extra-industry networks on performance: A case of venture capital portfolio firms. Managerial and Decision Economics, 35(2), 129-144.

Belussi, F., \& Staber, U. (Eds.) (2011). Managing networks of creativity. London: Routledge.

Belussi, F., Sedita, S., Ganzaroli, A., \& Orsi, L. (2015). Evolving through innovation and knowledge reutilisation: The case of L'Oréal. In F. Belussi, \& L. Orsi (Eds.), Innovation, alliances, and networks in high-tech environments. Abingdon: Routledge (forthcoming).

Benson, J. K. (1977). Organizations: A dialectical view. Administrative Science Quarterly, 22(1), 1-21.

Bijker, W. E. (1987). The social construction of Bakelite: Toward a theory of invention. In W. E. Bijker, T. P. Hughes, \& T. Pinch (Eds.), The social construction of technological systems: New directions in the sociology and history of technology (pp. 159-187). Boston: The MIT Press.

Bonaccorsi, A. (2011). A functional theory of technology and technological change. In C. Antonelli (Ed.), Handbook on the economic complexity of technological change (pp. 286-340). Cheltenham: Edward Elgar.

Bonifati, G. (2010). "More is different", exaptation and uncertainty: Three fundamental concepts for a complexity theory of innovation. Economics of Innovation and New Technology, 19(8), 743-760.

Bonifati, G., \& Villani, M. (2013). Exaptation in innovation processes: Theory and models. In A. Grandori (Ed.), Handbook of economic organization: Integrating economic and organization theory (pp. 172-192). Cheltenham: Edward Elgar.

Bourgeois, L. J, I. I. I. (1984). Strategic management and determinism. Academy of Management Review, 9(4), 586-596.

Breslin, D. (2008). A review of the evolutionary approach to the study of entrepreneurship. International Journal of Management Reviews, 10(4), 399-423. 
Breslin, D. (2011). Interpreting futures through the multi-level co-evolution of organizational practices. Futures, 43(9), 1020-1028.

Breslin, D. (2014). Calm in the storm: Simulating the management of organizational co-evolution. Futures, 57(1), 62-77.

Breslin, D. (2015). What evolves in organizational co-evolution? Journal of Management and Governance, doi:10.1007/s10997-014-9302-0.

Burgelman, R. A. (1991). Intraorganizational ecology of strategy making and organizational adaptation: Theory and field research. Organization Science, 2(1), 239-262.

Cafferata, R. (1984). Teoria dell'organizzazione. Un approccio non contingente. Milan: Franco Angeli.

Cafferata, R. (1987). Un'interpretazione dialettica del rapporto tra impresa e ambiente esterno. Finanza marketing e produzione, 2, 69-108.

Cafferata, R. (2014a). Management in adattamento. Tra razionalità economica, evoluzione $e$ imperfezione dei sistemi. Bologna: Il Mulino.

Cafferata, R. (2014b). Darwinist connections between the systemness of social organizations and their evolution. Journal of Management and Governance, doi:10.1007/s10997-014-9303-z.

Campbell, D. (1965). Variation, selection and retention in sociocultural evolution. In H. R. Barringer, G. I. Blanksten, \& R. W. Mack (Eds.), Social change in developing areas: A reinterpretation of evolutionary theory (pp. 19-49). Cambridge: Schenkman.

Carayannis, E. G., \& Campbell, D. F. J. (2009). "Mode 3" and "Quadruple Helix": Toward a 21st century fractal innovation ecosystem. International Journal of Technology Management, 46(3/4), 201-234.

Carney, M., \& Gedajlovic, E. (2002). The co-evolution of institutional environments and organizational strategies: The rise of family business groups in the ASEAN region. Organization Studies, 23(1), $1-29$.

Cattani, G., \& Ferriani, S. (2008). A core/periphery perspective on individual creative performance: Social networks and cinematic achievements in the Hollywood film industry. Organization Science, 19(6), 824-844.

Chesbrough, H. (2003). Open innovation: The new imperative for creating and profiting from technology. Boston: Harvard Business School Press.

Child, J., Tse, K., \& Rodrigues, S. B. (2013). The dynamics of corporate co-evolution. Cheltenham: Edward Elgar.

Cohen, W., \& Levinthal, D. (1990). Absorptive capacity: A new perspective on learning and innovation. Administrative Science Quarterly, 35(1), 128-152.

Cordes, C. (2006). Darwinism in economics: From analogy to continuity. Journal of Evolutionary Economics, 16(5), 529-541.

Dantas, E., \& Bell, M. (2011). The co-evolution of firm-centered knowledge networks and capabilities in late industrializing countries: The case of Petrobras in the offshore oil innovation system in Brazil. World Development, 39(9), 1570-1591.

Darwin, C. R. (1859). On the origin of species by means of natural selection or the preservation of favoured races in the struggle for life. London: John Murray.

Dennett, D. (1995). Darwin's dangerous idea. New York: Simon and Schuster.

Dew, N., Sarasvathy, S. D., \& Venkataraman, S. (2004). The economic implications of exaptation. Journal of Evolutionary Economics, 14(1), 69-84.

Di Stefano, G., Peteraf, M. A., \& Verona, G. (2010). Dynamic capabilities deconstructed: A bibliographic investigation into the origins, development, and future directions of the research domain. Industrial and Corporate Change, 19(4), 1187-1204.

Djelic, M. L., \& Ainamo, A. (1999). The co-evolution of new organizational forms in the fashion industry: A historical and comparative study of France, Italy, and the United States. Organization Science, 10(5), 622-637.

Dobson, S. (2012). Characterizing the evolution of commercial organizational spaces. International Journal of Organizational Analysis, 20(3), 309-322.

Dobson, S., \& Jorgensen, A. (2015). Increasing the resilience and adaptive capacity of cities through entrepreneurial urbanism. International Journal of Globalisation and Small Business (forthcoming).

Dollimore, D., \& Gomes, E. (2014). The meaning of evolutionary language in the study of organizations: Lost in translation? Paper presented at the WINIR inaugural conference, Greenwich, UK.

Dosi, G. (1982). Technological paradigms and technological trajectories. Research Policy, 11(3), $147-162$. 
Dosi, G., Levinthal, D. A., \& Marengo, L. (2003). Bridging contested terrain: Linking incentive-based and learning perspectives on organizational evolution. Industrial and Corporate Change, 12(2), $413-436$.

Durand, R. (2006). Organizational evolution and strategic management. London: Sage Publications.

Eisenhardt, K., \& Martin, J. (2000). Dynamic capabilities: What are they? Strategic Management Journal, 21(10/11), 1105-1121.

Ethiraj, S. K., \& Levinthal, D. A. (2004). Bounded rationality and the search for organizational architecture: An evolutionary perspective on the design of organizations and their evolvability. Administrative Science Quarterly, 49(3), 404-437.

European Science Foundation's Standing Committee for the Social Sciences. (2013). The good, the bad and the ugly. Understanding collaboration between the social sciences and the life sciences. Strasbourg: Ireg Strasbourg.

Feldman, M. S., \& Pentland, B. T. (2003). Reconceptualizing organizational routines as a source of flexibility and change. Administrative Science Quarterly, 48(1), 94-118.

Flier, B., Van den Bosch, F. A. J., \& Volberda, H. K. (2003). Co-evolution in the strategic renewal behaviour of British, Dutch and French financial incumbents: Interaction of environmental selection, institutional effects and managerial intentionality. Journal of Management Studies, 40(8), 2163-2188.

Fortune, A., \& Mitchell, W. (2012). Unpacking firm exit at the firm and industry levels: The adaptation and selection of firm capabilities. Strategic Management Journal, 33(7), 794-819.

Freeman, C. (1982). The economics of industrial innovation. London: Frances Pinter.

Freeman, C. (Ed.) (1984). Long waves in the world economy. London: Frances Pinter.

Furnari, S. (2014). Interstitial spaces: Micro-interaction settings and the genesis of new practices between institutional fields. Academy of Management Review, 39(4), 439-462.

Gatti, C., Volpe, L., \& Vagnani, G. (2015). Interdependence among productive activities: Implications for exploration and exploitation. Journal of Business Research, 68(3), 711-722.

Geels, F. W. (2002). Technological transitions as evolutionary reconfiguration processes: A multi-level perspective and a case study. Research Policy, 31(8/9), 1257-1274.

Gill, J. (2012). An extra-memetic empirical methodology to accompany theoretical memetics. International Journal of Organizational Analysis, 20(3), 323-336.

Gould, S. J. (1982). Darwinism and the expansion of evolutionary theory. Science, 216(4544), 380-387.

Gould, S. J., \& Eldredge, N. (1977). Punctuated equilibria: The tempo and mode of evolution reconsidered. Paleobiology, 3(2), 115-151.

Gould, S. J., \& Vrba, E. S. (1982). Exaptation-A missing term in the science of form. Paleobiology, $8(1), 4-15$.

Hagedoorn, J., \& Duysters, G. (2002). External sources of innovative capabilities: The preference for strategic alliances or mergers and acquisitions. Journal of Management Studies, 39(2), 167-188.

Hargadon, A., \& Sutton, R. I. (1997). Technology brokering and innovation in a product development firm. Administrative Science Quarterly, 42(4), 716-749.

Helfat, C. E., \& Winter, S. G. (2011). Untangling dynamic and operational capabilities: Strategy for the (n)ever-changing world. Strategic Management Journal, 32(11), 1243-1250.

Helfat, C. E., Finkelstein, S., Mitchell, W., Peteraf, M. A., Singh, H., Teece, D. J., \& Winter, S. G. (2007). Dynamic capabilities: Understanding strategic change in organizations. Oxford: Blackwell Publishing.

Hodgson, G. M. (2010). Darwinian coevolution of organizations and the environment. Ecological Economics, 69(4), 700-706.

Hodgson, G. M. (2013). Understanding organizational evolution: Toward a research agenda using generalized Darwinism. Organization Studies, 34(7), 973-992.

Hodgson, G. M., \& Knudsen, T. (2010). Darwin's conjecture: The search for general principles of social and economic evolution. Chicago: University of Chicago Press.

Hrebiniak, L. G., \& Joyce, W. M. (1985). Organizational adaptation: Strategic choice and environmental determinism. Administrative Science Quarterly, 30(3), 336-349.

Hull, D. L. (1988). Science as a process. Chicago: The University of Chicago Press.

Huygens, M., Van den Bosch, F. A. J., Volberda, H. K., \& Baden-Fuller, C. (2001). Co-evolution of firm capabilities and industry competition: Investigating the music industry, 1877-1997. Organization Studies, 22(6), 971-1011.

Inkpen, A. (2000). Learning throughout joint ventures: A framework of knowledge acquisition. Journal of Management Studies, 37(7), 1019-1044. 
Jenkins, M., \& Floyd, S. (2001). Trajectories in the evolution of technology: A multi-level study of competition in Formula One racing. Organization Studies, 22(6), 945-969.

Johansson, T., \& Kask, J. (2013). On the promise and premises of a Darwinian theory in research on business relationships. Industrial Marketing Management, 42(3), 306-315.

Jones, C. (2001). Co-evolution of entrepreneurial careers, institutional rules and competitive dynamics in American film, 1895-1920. Organization Studies, 22(6), 911-944.

Jones, C. (2005). Firm transformation: Advancing a Darwinian perspective. Management Decision, 43(1), $13-25$.

Koza, M. P., \& Lewin, A. Y. (1999). The co-evolution of network alliances: A longitudinal analysis of an international professional service network. Organization Science, 10(5), 638-653.

Koza, M. P., Tallman, S., \& Ataay, A. (2011). The strategic assembly of global firms: A micro-structural analysis of local learning and global adaptation. Global Strategy Journal, 1(1/2), 27-46.

Laland, K., Uller, T., Feldman, M., Sterelny, K., Müller, G. B., Moczek, A., et al. (2014). Does evolutionary theory need a rethink? Nature, 514, 161-164.

Lane, D. (2011). Complexity and innovation dynamics. In C. Antonelli (Ed.), Handbook on the economic complexity of technological change (pp. 63-80). Cheltenham: Edward Elgar.

Lane, D., \& Maxfield, R. (2005). Ontological uncertainty and innovation. Journal of Evolutionary Economics, 15(1), 3-50.

Langton, J. (1984). The ecological theory of bureaucracy: The case of Josiah Wedgwood and the British pottery industry. Administrative Science Quarterly, 29(3), 330-335.

Larson, G., Stephens, P. A., Tehrani, J. J., \& Layton, R. H. (2013). Exapting exaptation. Trends in Ecology \& Evolution, 28(9), 497-498.

Lawless, M. W., \& Finch, L. K. (1989). Choice and determinism: A test of Hrebiniak and Joyce's framework on strategy-environment fit. Strategic Management Journal, 10(4), 351-365.

Levinthal, D. A. (1991). Organizational adaptation and environmental selection-Interrelated processes of change. Organization Science, 2(1), 140-145.

Levinthal, D. A. (1992). Surviving Schumpeterian environments: An evolutionary perspective. Industrial and Corporate Change, 1(3), 427-443.

Levinthal, D. A. (1998). The slow pace of rapid technological change: Gradualism and punctuation in technological change. Industrial and Corporate Change, 7(2), 217-247.

Levinthal, D. A., \& Myatt, J. (1994). Co-evolution of capabilities and industry: The evolution of mutual fund processing. Strategic Management Journal, 15(15), 45-62.

Levitt, B., \& March, J. (1988). Organizational learning. Annual Review of Sociology, 14(1), 319-340.

Lewin, A. Y., \& Koza, M. P. (2001). Empirical research in co-evolutionary processes of strategic adaptation and change: The promise and the challenge. Organization Studies, 22(6), 5-12.

Lewin, A. Y., \& Volberda, H. K. (2005). The future of organization studies: Beyond the selectionadaptation debate. In H. Tsoukas \& C. Knudsen (Eds.), The Oxford handbook of organization theory (pp. 568-595). Oxford: Oxford University Press.

Lewin, A. Y., \& Volberda, H. K. (2011). Co-evolution of global sourcing: The need to understand the underlying mechanisms of firm-decisions to offshore. International Business Review, 20(3), 241-251.

Lord, A. S. (2012). Reviving organisational memetics through Cultural Linnæanism. International Journal of Organizational Analysis, 20(3), 349-370.

Marquis, C., \& Huang, Z. (2010). Acquisitions as exaptation. The legacy of founding institutions in the U.S. Commercial banking industry. Academy of Management Journal, 53(6), 1441-1473.

Mastrogiorgio, M. (2013). Technological exaptation: Evidence from patent data. Paper presented at the Academy of Management annual conference, Orlando, August.

Mazzucato, M. (2013). The entrepreneurial State: Debunking public v.s private sector myths. London: Anthem.

Mazzucato, M., \& Tancioni, M. (2008). Innovation and idiosyncratic risk: An industry- and firm-level analysis. Industrial and Corporate Change, 17(4), 779-811.

McCarthy, I. P. (1995). Manufacturing classification: Lessons from organizational systematics and biological taxonomy. Integrated Manufacturing Systems, 6(6), 37-48.

McCarthy, I. P., Leseure, M., Ridgway, K., \& Fieller, R. (1997). Building a manufacturing cladogram. International Journal of Technology Management, 13(3), 269-286.

McCarthy, I. P., Lawrence, T. B., Wixted, B., \& Gordon, B. R. (2010). A multidimensional conceptualization of environmental velocity. Academy of Management Review, 35(4), 604-626. 
Meyer, C. B., \& Stensaker, I. G. (2006). Developing capacity for change. Journal of Change Management, 6(2), 217-231.

Mokyr, J. (2000). Natural history and economic history: Is technological change an evolutionary process? Working paper, Northweastern University, Departments of Economics and History.

Moore, J. F. (1993). Predators and prey: A new ecology of competition. Harvard Business Review, 71(3), 75-86.

Murmann, J. P. (2003). Knowledge and competitive advantage: The co-evolution of firms, technology and national institutions. New York: Cambridge University Press.

Murmann, J. P. (2013). The co-evolution of industries and important features of their environments. Organization Science, 24(1), 58-78.

Najat, A., \& Maclean, M. (2013). Co-evolution, opportunity seeking and institutional change: Entrepreneurship and the Indian telecommunications industry, 1923-2009. Business History, 55(1), 29-52.

Nelson, R. R., \& Winter, S. G. (1982). An evolutionary theory of economic change. Cambridge: Bellknap.

Pacheco, D., York, J. G., Dean, T. J., \& Sarasvathy, S. D. (2010). The co-evolution of institutional entrepreneurship: A tale of two theories. Journal of Management, 36(4), 974-1010.

Parmigiani, A., \& Howard-Grenville, J. (2011). Routines revisited: Exploring the capabilities and practice perspectives. The Academy of Management Annals, 5(1), 413-453.

Penrose, E. T. (1959). The theory of the growth of the firm. London: Wiley.

Pentland, B. T., \& Feldman, M. S. (2005). Organizational routines as a unit of analysis. Industrial and Corporate Change, 14(5), 793-815.

Pentland, B. T., Feldman, M. S., Becker, M. C., \& Liu, P. (2012). Dynamics of organizational routines: A generative model. Journal of Management Studies, 49(8), 1484-1508.

Pettigrew, A. M. (1987). Context and action in the transformation of the firm. Journal of Management Studies, 24(6), 649-670.

Powell, W. W. (1990). Neither market nor hierarchy: Network forms of organization. Research in Organizational Behavior, 12, 295-336.

Powell, W. W., Koput, K. W., \& Smith-Doerr, L. (1996). Interorganizational collaboration and the locus of innovation: Networks of learning in biotechnology. Administrative Science Quarterly, 41(1), $116-145$.

Price, I. (2012). The selfish signifier: Meaning, virulence and transmissibility in a management fashion. International Journal of Organizational Analysis, 20(3), 337-348.

Price, I., \& Shaw, R. (1998). Shifting the patterns. Breaching the memetic codes of corporate performance. Chaldford: Management Books.

Rerup, C., \& Feldman, M. S. (2011). Routines as a source of change in organizational schemata: The role of trial-and-error learning. Academy of Management Journal, 54(3), 577-610.

Rodrigues, S., \& Child, J. (2003). Co-evolution in an institutionalized environment. Journal of Management Studies, 40(8), 2137-2162.

Rosenberg, N. (1976). Perspectives on technology. Cambridge: Cambridge University Press.

Rosenberg, N. (1982). Inside the black box. Technology and economics. Cambridge: Cambridge University Press.

Schulz, M. (2002). Organizational learning. In J. A. C. Baum (Ed.), The Blackwell companion to organizations (pp. 415-441). Oxford: Blackwell Publishing.

Schumpeter, J. (1934). The theory of economic development. Cambridge: Harvard University Press.

Schumpeter, J. (1947). The creative response in history. Journal of Economic History, 7(2), 149-159.

Sorenson, O., Rivkin, J. V., \& Fleming, L. (2006). Complexity, networks and knowledge flow. Research Policy, 35(7), 994-1017.

Stoelhorst, J. W., \& Richerson, P. J. (2013). A naturalistic theory of economic organization. Journal of Economic Behavior \& Organization, 90S, S45-S56.

Teece, D. J. (2007). Explicating dynamic capabilities: The nature and microfoundations of (sustainable) enterprise performance. Strategic Management Journal, 28(13), 1267-1369.

Teece, D., Pisano, G., \& Shuen, A. (1997). Dynamic capabilities and strategic management. Strategic Management Journal, 18(7), 509-533.

Tushmann, M., \& Anderson, P. (1986). Technological discontinuities and organizational environments. Administrative Science Quarterly, 31(3), 439-465.

Vagnani, G. (2012). Exploration and long-run organizational performance The moderating role of technological interdependence. Journal of Management,. doi:10.1177/0149206312466146. 
Volberda, H. W., \& Lewin, A. Y. (2003). Co-evolutionary dynamics within and between firms: From evolution to co-evolution. Journal of Management Studies, 40(8), 2111-2136.

Volberda, H. W., Van den Bosch, F. A. J., \& Mihalache, O. R. (2014). Advanding management innovation? Synthesizing processes, levels of analysis, and change agents. Organization Studies, 35(9), 1245-1264.

Watts, D. (2002). A simple model of global cascades on random networks. Applied Mathematics, 99(9), 5766-5771.

Weick, K. E. (1969). The social psychology of organizing. Reading: Addison-Wesley.

Whittington, R. (1988). Environmental structure and theories of strategic choice. Journal of Management Studies, 25(6), 521-536.

Winter, S. G. (2003). Understanding dynamic capabilities. Strategic Management Journal, 24(10), 991-995.

Witt, U. (2004). On the proper interpretation of "evolution" in economics and its implications for production theory. Journal of Economic Methodology, 11(2), 125-146.

Zollo, M., \& Winter, S. G. (2002). Deliberate learning and the evolution of dynamic capabilities. Organization Science, 13(3), 339-351.

Gianpaolo Abatecola is an Associate Professor of Management at the University of Rome "Tor Vergata", Department of Business Government Philosophy Studies. His main research interests and publications lie in the fields of organizational evolution and co-evolution, managerial decision making and behavioral strategy. On these themes, he has also taught in various universities across Europe and the US. Since 2012, Dr. Abatecola has been serving the Annual Conference of the European Academy of Management as a co-chair of the track about "Darwinism, organizational evolution, and survival".

Fiorenza Belussi is a Full Professor of Management at the University of Padua. She has participated in several international projects financed by the EU. Her areas of interest include: (a) Management of innovation and creativity, creative industries, theoretical models on innovation diffusion through gatekeepers; studies of open innovation, local systems of innovation, and (b) International business and the impact of globalisation on local economies. She has published more than 190 articles and book chapters. Among others, she has published in: International Journal of Technology Management, Futures, European Planning Studies, Research Policy, Cambridge Journal of Economics, Urban Studies, Entrepreneurship \& Regional Development, Industry \& Innovation, Regional Studies, and numerous Italian journals.

Dermot Breslin is a Lecturer at Sheffield University Management School, Adjunct Professor at Saarlandes University Germany and Visiting Professor at the University of Rome "Tor Vergata". His research focuses on the emergence and co-evolution of behaviours within social groups and organizations. Studies to date have included the home care industry, hi-tech start-ups, domestic fire risk behaviours and group creativity. He is currently associate editor for the International Journal of Management Reviews.

Igor Filatotchev is a Professor of Corporate Governance and Strategy and Associate Dean for Research and Enterprise at Cass Business School, City University London. He earned his Ph.D. in Economics from the Institute of World Economy and International Relations (Moscow, the Russian Federation). His research interests are focused on a fast growing area in the management and economics literature relating to corporate governance effects on entrepreneurship development, strategic decisions and organizational change. He has published extensively in the fields of corporate governance and strategy in leading academic journals such as: Academy of Management Journal, Academy of Management Perspectives, Strategic Management Journal, Organization Science, Journal of Management, Journal of International Business Studies, and Journal of Management Studies. 